\title{
Examining sex differences in the use of direct and indirect aggression
}

\author{
Sibylle Artz, Diana Nicholson \& Douglas Magnuson \\ School of Child and Youth Care \\ University of Victoria
}

August 1, 2008

\begin{abstract}
Direct and indirect aggressive behaviors were studied using surveys and interviews of students in two public schools. The variables of "sex-of-aggressor" and "sex-of-target were included. Claims in previous research that girls engage in far more indirect aggression than boys are not supported. Further, it was found that girls are more likely to target the opposite sex with direct aggression than boys. This suggests more gender fluidity in the use of aggression by girls and adds to a growing body of research that dispels the notion that direct and indirect aggression can be neatly sorted into male and female categories of behavior.
\end{abstract}

Keywords: aggression, sex differences, direct aggression, indirect aggression, prevalence and preferences for forms of aggression, sex of target 

This article reports on research that calls into question the notion that the use of aggression and violence can be neatly categorized according to sex and that girls generally employ indirect forms of aggression while boys generally employ direct forms of aggression.

Whether the focus of inquiry is physical or verbal observable aggression, as it was for much of the twentieth century (Vaillancourt 2005), or non-observable aggression (a form of aggression that has garnered much interest especially in those focusing on female use of aggression), Gendreau and Archer (2005) point out, that those who study aggression work neither with a universally agreed upon definition of the construct nor with a single coherent theoretical and practical framework. There is a similar problem with the research on violence. As Burman, Brown and Batchelor (2003) state, "Exploring the nuanced meanings of violence...[is] exacerbated by the overarching problem of the contested meanings of the term 'violence', which we encountered at a theoretical, methodological analytic level” (p. 73). Either construct (aggression or violence) presents us with definitional challenges.

Research on non-observable aggression like shunning, deliberate exclusion, gossip or rumor mongering, the silent treatment and the like, has thus far employed three different concepts or terms (see Vaillancourt, 2005 for a thorough discussion). The first of these three concepts is relational aggression, a term coined by Crick (1993) to refer to behaviors used to damage other people's relationships, feelings of acceptance, and social inclusion. Relational aggression has also been applied to behaviors like a) indirectly excluding or socially manipulating a person by using another's relationship with that person as the vehicle for harm (Cullerton-Sen \& Crick, 2005); b) actions such as keeping 
someone out of a group, saying you will not be friends with someone, ignoring a person, telling rumors or lies about someone you are mad at (Henington, Hughes, Cavell, \& Thompson, 1998); and c) threatening to end a friendship or no longer talking to someone, and deliberately excluding someone socially (Werner \& Nixon, 2005).

The second term, social aggression, used by Galen and Underwood (1997), Cairns, Cairns, Neckarman, Ferguson, and Gariepy (1989), and Xie, Cairns and Cairns (2002) refers to aggressive behavior that is intended to damage another person's selfesteem but does not focus on disrupting that person's social relationships. This kind of aggression is focused more on making targets feel badly about themselves or afraid for their own safety without directly engaging in directly attacking them.

The third concept, indirect aggression, coined in the late 1980s by Lagerspetz, Björkqvist and Peltonen (1988), refers to a form of aggression in which "the instigator manipulates others to attack the victim, or by other means, makes use of the social structure in order to harm the target person” (Björkqvist \& Niemelä, 1992, p.8). Instigating others to act aggressively against a target can involve gossiping, telling false or bad stories, becoming friends with another person as revenge, secretly planning to bother another person, saying bad things behind a person's back, suggesting that others be excluded from interaction, telling another person's secrets to a third person, writing nasty notes about someone, and trying to get others to dislike a person (Björkqvist, Österman, \& Kaukianen, 1992).

Additionally, Björkqvist, et al., (1992) suggest that the term indirect aggression can also been used to distinguish between physical and non-physical aggression, aggression with and without a target and harm delivered directly but not physically 
versus in a circuitous fashion. Finally, Tremblay (2000) offers a simple definition of indirect aggression: "Behavior aimed at hurting someone without the use of physical aggression” (p.20). Given that variety of ways in which non-physical aggression has been described, those who study such aggression always find themselves having to make choices about which term to use and, consequently, which discourse to privilege. We explain our choices in our description of our methods.

Investigating sex differences in aggressive behavior

Research on sex differences in the use of aggression shows that boys are implicated in direct physical forms of aggression more than girls (Archer, 2004). A large body of research on indirect aggression (see Archer, 2004 for a meta-analytic review) focuses on whether or not girls use this kind of aggression more than boys (c.f., ZimmerGembeck, Geiger, \& Crick, 2005; Vaillancourt \& Hymel, 2004). It was originally thought that indirect aggression, particularly the kind of indirect aggression described as relational or social aggression, is used more frequently by girls than by boys (Crick, 1993; Crick \& Grotpeter, 1995, 1996). Vaillancourt (2005) seems to agree that girls do use more indirect violence than boys and states “...studies have consistently demonstrated that females are typically more indirectly aggressive then males, whereas males are invariably more physically aggressive than females” (p. 161). However, Vaillancourt (2005) also notes that there have been some studies that show no sex difference in the use of indirect aggression and some that found males to be more indirectly aggressive than females.

These variations in sex differences have been linked to age differences: In early childhood, aggression tends to be mostly physical for both sexes (Björkqvist \& Niemelä, 
1992; Tremblay, 2000). With the development of verbal skills, verbally-aggressive behavior often replaces physical aggression, and since girls as a group tend to acquire verbal skills earlier than boys, girls begin using verbal and indirect aggression sooner than boys. Zimmer-Gembeck et al., (2005) support the notion of an age-related, developmental progression in the kind of aggression used by boys and girls. Using peer nomination, they found no sex difference in the use of rumor-spreading, social exclusion, and ignoring and threatening to end friendships among boys and girls in grade 3 but a significant sex difference at grade 6 with girls using more of these behaviors. However, in their research Little, Jones, Henrich and Hawley (2003) found that males' use of indirect aggression remained stable between ages 10 and 15 but that girls' use of indirect aggression declined during the same developmental period.

Björkqvist, Österman, and Kaukianen (1992) found that with age, boys and girls used verbal aggression more frequently than they used physical aggression and nonobservable, more covert forms of aggression. In their analyses, these researchers found that the use of direct verbal aggression climbed steeply around 11 years of age and remained high throughout adolescence. Atkin, Smith, Roberto, Fediuk and Wagner (2002) found that youth in the eighth grade were more verbally aggressive that seventhgraders; however, boys and girls did not differ with respect to frequency of using direct verbal aggression. Yubero and Navarro (2006) reported direct verbal aggression to be the most highly used form of aggression in the high schools they researched. Peterson and Rigby (1999) also found that boys and girls between 12 and 16 years of age reported being at the receiving end of being called hurtful names more frequently than they experienced other forms of non-observable, more covert forms of aggression. In an 
analysis of the frequency with which 13 to 14 year-old boys and girls experienced verbal abuse, Atkin et al. (2002) found that boys reported an average of 119 incidents per year while girls experienced an average of 100 incidents per year. Atkin et al. (2002) also reported a small but significant difference between girls and boys regarding the use of verbal aggression, with boys ranking higher than girls.

To further understand sex differences in the use of aggression researchers have attended to the sex of targets alongside the sex of aggressors (Card, Hodges, Little \& Hawley, 2005; Yubero \& Navarro, 2006). Examining sex of target also enables researchers to inquire into the possible culture- and gender-related factors that influence decision-making in the use of aggressive behavior (Kimmel \& Mahler, 2003; Lahelma, 2002).

Richardson and Green $(1999,2006)$ studied sex differences in the amount of and type of aggression (direct and indirect) aimed at same and opposite sex targets by college students. In their first study of sex of aggressor and sex of target in a young adult population (mean age 24 years) Richardson and Green (1999) found that all respondents reported that when they used direct aggression they targeted this more frequently towards males than towards females, but that indirect aggression was targeted with similar frequency towards males and females. Females, when compared within their gender group, reported expressing more indirect aggression than direct aggression, while males, when compared within their gender group, reported expressing similar amounts of direct and indirect aggression. When females and males were compared across gendered groups, females reported more indirect aggression towards female targets than males did; males reported targeting more direct aggression towards male targets than towards female 
targets, and females delivered similar amounts of direct aggression to male and female targets.

In a follow-up study on sex of aggressor and sex of target, Richardson and Green (2006) found that aggressive behavior varies as a function of the nature of the relationship of the conflicting parties (romantic partner or friend). Participants in the Richardson and Green (2006) study reported using more indirect aggression towards friends than towards romantic partners, in that same sex friends were the targets of higher levels of indirect aggression than opposite sex friends, opposite sex friends were the targets of more indirect aggression than romantic partners, and romantic partners were the targets of more direct aggression than either same or opposite sex friends. This suggests that relationship to target plays a key role in choices about which form of aggression to use against whom.

We add our study of a co-ed sample of adolescent public school students to the growing body of knowledge on sex roles and aggression and report on our findings with regard to sex differences in the use of indirect and direct aggression, including sex differences in target selection.

The Study

The study that we report on here is part of a larger study, a Canadian Institutes of Health Research (CIHR) funded New Emerging Team project entitled Aggressive and Violent Girls: Contributing Factors, Developmental Course and Intervention Strategies. ${ }^{1}$ We focused on the use of aggression and violence among adolescent females in suburban schools. Other research teams participating in the project focused on urban schools,

\footnotetext{
${ }^{1}$ The principal investigator on the team is Dr. Marlene Moretti; the co-investigators are: Dr. Marc LeBlanc, Dr. Candice Odgers, Dr. Nadine Lanctôt, Dr. Bonnie Leadbeater, Dr. Sibylle Artz.
} 
custody and treatment centers and, in some cases, on younger girls. Our research is the continuation of research on girls and school-based violence in which the first author has been involved since 1993 (Artz, 1998; Artz \& Riecken, 1994a, 1994b, 1995a, 1995b; Artz, Riecken, MacIntyre, Lam, \& Maczewski, 1997, 1998, 1999a, 1999b, 2000; Riecken, Artz, MacIntyre, Lam, \& Maczewski, 1998). This research, like our previous work, employed quantitative and qualitative methods.

In this article we report on our first wave of quantitative and qualitative data gathered specifically with regard to overt direct and observable aggression like hitting, punching, name-calling, swearing, and threatening and also indirect, covert, other-thanobservable aggression like shunning, deliberate exclusion, gossip or rumor mongering, the silent treatment, damaging property, blackmailing, and the like.

Two questions are the focus of what we report on here: Are there sex differences with respect to a) the prevalence of the use of various forms of aggression, and b) preferences for using specific forms of aggressive behavior towards males and females? We did not as Richardson and Green $(2006)^{2}$ did, ask about the aggressor's relationship to his or her target, and recognize this as a limitation of our study. Still we believe we have valuable information to add to the existing knowledge about sex differences and the use of direct and indirect aggression.

\section{Methods}

\section{Participants}

Participants were drawn from two public schools, a middle school and a high school in a mixed working and middle class neighborhood with a median household income of

\footnotetext{
2 Our study was conducted before Richardson and Green published their 2006 article. With the benefit of hindsight we acknowledge that investigating the relationship of aggressor and target would have been a useful addition to our study.
} 
over \$50,000 CDN.had participated with Artz (1993; 1998) in earlier research. The sample consisted of 264 students in grades 7 to 9 between 12 and 15 years of age $(M=13.49)^{3}$. The sample was relatively equally split between male $(\mathrm{N}=146)$ and female ( $\mathrm{N}=118$ ) participants. Participants were ethnically homogenous with the majority being Caucasian (average: 85\%) with English as their first language (average: 97\%). Given the demographics of our participants, we cannot speak to race and ethnicity or to class in our analysis. We recognize this as a limitation of our study and refer the reader to the comprehensive discussion of the importance of including an analysis of race, ethnicity and class in discussions of gender and deviance or crime offered by Messerschmidt (1995, 1997) and by Miller’s (2002) engagement with and enhancement of Messerschmidt's concepts. Messerschmidt and Miller underline the importance of avoiding a static grasp of gender. Messerschmidt’s concept of situated action and “doing gender” conceives of gender as grounded in dynamic social practices and as more than a mere trait or role variable that is known or assumed without reference to experience. None-the-less, gender is also practiced in homogenous groups, and we believe we can offer insight into sex differences in the use of aggression in such a group even while risking a too narrow grasp of the intersections that combine to create the performance of aggression and violence.

\section{Instruments}

We used self-report surveys to investigate the use of aggression. Self-report is a wellestablished method for investigating the use of aggression (see for example, Alder \& Worrall, 2004; Doob \& Cesaroni 2004; Hindelang, Hirschi, \& Weis, 1981; Sprott \&

\footnotetext{
3 Because our sample falls within a relatively restricted age range, we have chosen to not attempt to make age-related comparisons in our data and therefore cannot suggest how our results do or do not support the notion of developmental progression in aggressive behavior referenced earlier in this article.
} 
Doob, 2004; Werner \& Nixon, 2005). Data was obtained using The Survey of Student Life $(\mathrm{SSL})^{4}$, an instrument adapted from Artz and Riecken (1994a, 1994b). This survey is 8 pages long, has a scan able format, and consists of 181 questions and space at the end of the survey for comments.

In dealing with the varieties of definition of and orientation to all the behaviors that are seen as constituting some form of aggression we have, for the purposes of our study, taken the following steps: 1) From among the three constructs generally used to deal with non-observable forms of aggression (i.e., relational, social, indirect), we elected to use the construct indirect aggression as per Tremblay (2000), largely because, in our view, all aggression that is directed at others, whether it is indirect or direct, is ultimately relational and social. 2) In our survey, direct aggression included pushing/shoving, swearing at another person, threatening, and name-calling. Indirect aggression included spreading rumors, excluding/shunning, damaging property, and blackmailing. To assess the internal consistency of the measures within our survey Cronbach's alpha was computed for each form of aggression using data obtained from each school in which the surveys were administered. Cronbach's alpha values were above the .75 cutoff on every comparison. 3) We also retained the specific behaviors in our tables and results (as recommended by Smith, Cowie, Olafsson, \& Liefooghe, 2002) with the hope of maintaining transparency. 4) The various forms of aggression were assessed using scaled responses that asked a student to state how often in the past month he/she had engaged in the particular act towards boys and girls (e.g., "never," "1 - 3 times," "4 - 9 times," and “10+ times”).

\footnotetext{
${ }^{4}$ A copy of the survey can be obtained by contacting the authors.
} 


\section{Data Collection and Analysis}

Data collection took place in the high school in January 2004. Grade 9 students who had consented to participating in the study gathered in an auditorium for the purpose of completing the survey. Data collection in the middle school took place in February 2004. Here the survey was administered during the same single class period in individual classrooms. Our total sample in this study includes 131 grade 9 students from the high school, and 133 students in grades 7 and 8 from the middle school.

We structured our analysis by first exploring frequencies and sex differences for specific behaviors (i.e., engagement in beating up another kid, pushing/shoving, swearing at another person, threatening, name-calling, or-spreading rumors, excluding/shunning, damaging property, and blackmailing), as well as reporting the frequencies and sex differences for the categories of direct and indirect aggressive behavior.

After analyzing the survey results, we conducted individual taped interviews (December 2004 through February 2005) about peer-to-peer use of aggression with ten students: five girls and five boys in a public middle school (13-14 years of age) who had previously completed our survey. The purpose of these interviews was to assist us with understanding our survey findings from the perspective of the participants. We therefore referred to the survey during our interviews and asked our participants open ended questions about who uses the various forms of direct and indirect aggression queried by

the survey, why they use these different forms of aggression, what they think makes kids do those things to each other, and what happens when kids do those things to each other. We transcribed the tapes and organized the participants' responses into direct quotes per 
each question, which we compared for similarities and differences and themes and patterns of response.

Results

\section{Sex Differences in Prevalence}

Respondents were asked whether they had beaten up another kid in the past year. Almost 42 percent $(\mathrm{N}=61)$ of males and 13.6\% $(\mathrm{N}=16)$ of females reported having beaten up another kid in the past year. As expected, males reported significantly higher use of this form of aggression $\left(\chi^{2}(\mathrm{df}=1)=25.15\right.$, p. $\left.>.001\right)$. But a different pattern emerged when we examined the additional forms of aggression under review, especially when we paid attention to sex of target (see Table 1).

\section{Insert Table 1 here}

Table 1 shows the percentages for various acts of aggression ("never," "1-3 times,” “4-9 times,” “10+ times,” in the past month), as reported by the respondents regarding their use towards male and female targets. What stands out is the high frequencies for some of these behaviors, especially swearing, name calling, and pushing and shoving directed at males. Respondents reported that in the month previous to the survey, 8/10 males and 5/10 females called males names; about 7.5/10 males and 5/10 females swore at males; 7.5/10 males and 5/10 females pushed/shoved males; 5/10 males and 2/10 females threatened males; 3.5/10 males and 3/10 females excluded /shunned males; and 2/10 males and 1/10 females spread rumors about males. As well, 5/10 males and 6/10 females called females names; 5/10 males and 5/10 females swore at females; 
2/10 males and 3.5/10 females pushed/shoved females; 1/10 males and 2/10 females threatened females; 2/10 males and 2.5/10 females excluded/shunned females; and 2/10 males and 1.5/10 females spread rumors about females. Further, 1.5/10 males reported blackmailing males while 1/10 males blackmailed females; 3/10 males damaged property belonging to other males and 1/10 males damaged property belonging to females. Less than 1/10 females reported blackmailing males and blackmailing females, while just over 1/10 females reported damaging property belonging to males and property belonging to females. Both males and females reported in engaging in all the behaviors that we queried, but at different rates, and both males and females crossed gender lines with respect to sex of target.

Sex Differences in Choice of Target

Using t-tests between mean scores for males' and females’ self-reported engagement in a number of aggressive acts, we found a number of significant differences with respect to choice of target (see Table 2).

Insert Table 2 about here

As Table 2 shows, males reported that they called males names, swore at males, pushed and shoved males, and threatened males (direct forms of aggression) at significantly higher rates than females did. Significant sex differences were also found for males' engagement in blackmailing males and damaging property belonging to males. Females reported that they threatened females and pushed and shoved females (direct forms of aggression) at rates significantly higher than males did, but we found no significant sex 
differences for swearing at females or calling females names (also direct forms of aggression). Additionally, we found no significant sex differences for spreading rumors and excluding/shunning males and females (indirect forms of aggression).

In order to determine whether males and females show a preference for using either direct or indirect aggression we combined the various acts of aggression that comprise direct and indirect aggression and compared the mean scores for males and females, without specifying sex of target, using t-tests. We found there was a significant sex difference in use of direct aggression with males using direct aggression significantly more than females, but no significant sex difference with respect to use of indirect aggression (see Table 3).

Insert Table 3 about here

Table 3 shows that our results are consistent with those obtained by others (c.f., Archer, 2004) in that we appear to have once again established a between-sex group difference with regard to direct aggression and shown that males use direct aggression more than females. As well, having found no significant difference between males and females with respect to their use of indirect aggression, we seem to be aligning ourselves with a considerable body of researchers who have reported similar results (Craig, 1998; David \& Kistner, 2000; Hennington, Hughes, Cavell \& Thompson, 1998; Little, Jones, Henrich \& Hawley, 2003; Roecker, Caprini, Dickerson, Parks \& Barton, 1999); researchers who have critiqued the notion that girls and boys can be neatly separated into discrete categories according to behavioral differences. But while we found that the male participants in our study reported an overall greater use of direct aggression we did not 
immediately interpret the significant difference in incidence levels for the use of direct aggression as indicative of an overall preference for direct aggression among males. After all, our findings showed that girls also used direct aggression and both sexes employed indirect aggression about equally. We therefore examined the sex differences in the preferences for the various forms of aggression that we investigated by asking the question: is there a significant difference in the order in which aggressive behaviors are ranked by males and females? To test for this we conducted a Wilcoxon Rank Sum Test for the two lists found in Tables 4 and 5. The Rank Sum Test is a test of the null hypothesis that the two rank sums based on independent samples drawn from the same population will be the same. In this case, the Wilcoxon Rank Sum Test score was not significantly different and suggests that the order in which girls and boys rank their preferences for the use of various kinds of aggression per sex of target is not very different. Although much has been made about the higher prevalence of male use of direct aggression, our data do not support a meaningful difference.

Insert Table 4 about here

Insert Table 5 about here

Tables 4 and 5 show that both males and females rank the use of direct aggressive behaviors ahead of indirect aggressive behaviors although the order of the type of aggression by sex of target seems to be different for males and females. Males reported targeting males ahead of females in that the first aggression toward females by males is 
the $5^{\text {th }}$ variable in the males' list while the first aggression by females towards males is second in the females' list. Males rank the aggressive behaviors used against same-sex targets higher than the aggressive behaviors that they use against opposite-sex targets. Females, while reporting lower means for the use of aggression against males than the males report, never-the-less rank opposite-sex target behaviors higher than males do and thus seem to involve themselves with opposite-sex targets more readily than males.

To better understand if sex of target plays a role with regard to the use of both direct and indirect aggression, we created new scales:

1. Same-Sex Direct Aggression composed of male-to-male and female-to-female aggression on the variables Called Names, Swore At, Pushed/Shoved, and Threatened.

2. Opposite-Sex Direct Aggression composed of male-to-female and female-to-male aggression on the variables Called Names, Swore At, Pushed/Shoved, and Threatened.

3. Same-Sex Indirect Aggression composed of male-to-male and female-to-female aggression on the variables Blackmailed, Damaged Property, Excluded/Shunned and Spread Rumors.

4. Opposite-Sex Indirect Aggression composed of male-to-female and female-tomale aggression on the variables Blackmailed, Damaged Property, Excluded/Shunned and Spread Rumors.

Each of these variables includes both males and females, since the distinction here is same-sex aggression and opposite-sex aggression, not just sex of the aggressor. The scores on these variables are dichotomous, with "yes" to indicate that they did participate 
in this type of aggression and "no" to indicate that they did not, and given that we are interested in whether aggressors are more likely to choose same-sex or opposite-sex targets when they use indirect and direct aggression, we calculated chi-squares, odds, and odds ratios using the data from these new composite variables. Same-Sex or Opposite Sex Targets?

Table 6 shows the frequencies for self-reported use of direct aggressive behaviors for same-sex and opposite-sex targets. If the sex of the target of the direct aggression does not matter, we would expect the frequencies for the self-reported use of direct aggression to be similar for same-sex and opposite-sex targets, but a chi-square calculation of the differences for the use or non-use of direct aggression shows a significant difference $\left(\chi^{2}(\mathrm{df}=1)=108, \mathrm{p} .>.001\right)$, indicating that sex of target may be a factor in the use of direct aggression.

To help understand what difference sex of target makes, and to whom, we calculated odds and odds ratios to explore similarities and/or differences between males and females with respect to the use of direct aggression. First, we calculated the overall odds - with males and females together - that, if there is direct aggression, it will be towards a same-sex target. The odds that the target will be same-sex for both males and females is 1.76 , suggesting that it is almost twice as likely that an act of direct aggression will be against a same-sex target. But the odds for males and females, calculated separately, suggest that this plays out differently for males and for females as follows: The odds that males will use direct aggression against a same-sex target rather than an opposite-sex target is 2.85, while the odds that females will use direct aggression against a same-sex target is 1.27. In other words, males are more likely than females to choose a 
same-sex target. This was further confirmed by our odds ratio calculation of the comparison between same-sex direct aggression for males to females: 2.24 , which shows that it is more than twice as likely that a male will use direct aggression against another male than will a female against another female.

Table 7 shows the frequencies for self-reported use of indirect aggressive behaviors for same-sex and opposite-sex targets. Again, we were interested in whether the sex of target matters, and here too found a significant difference $\left(\chi^{2}(\mathrm{df}=1)=11.77\right.$, $\mathrm{p}$. $>$.001), thus indicating that sex of target also appears to matter when it comes to the use of indirect aggression. So while there may be no significant between-group sex difference for the use of indirect aggression, there is still a significant difference for both sexes when the sex of the chosen target is factored into the equation.

The overall odds - with males and females together - that, if there is indirect aggression, the target will be of the same sex as the aggressor is 1.50. This suggests that it is one and one-half times more likely that the target of indirect aggression for either males or females will be of the same sex rather than the opposite sex. But as with direct aggression, when the odds for males and females are calculated separately, different odds values emerge for each sex: The odds that a male will use indirect aggression against another male is 2.57 , while the odds that a female will use indirect aggression against another female is 1.44 , and the odds ratio for the use of indirect aggression for males and females is 1.78 . Hence, our calculations indicate that males are almost twice as likely as females to choose a same-sex target when they use indirect aggression. In sum, for both direct and indirect aggression, males are far more likely than females to choose a samesex target. 


\section{Qualitative Interview Findings}

In interviews we asked youth about peer-to-peer use of direct aggression in the forms of name-calling and swearing - the two forms of direct aggression that were most prevalent in our survey results and about the social arrangements with regard to who uses these forms of aggression and for what purpose. We share excerpts from their interviews below, beginning with the girls.

One of the girls told us, "The "popular girls" call other girls "slut, ho, bitch, fat", mostly because of what girls wear or if girls are trying to get guys' attention” (D0177/78, p.13). Another girl pointed out that, "All the time I hear it ["slut" name-calling]. They, the guys, all the cool guys call them whores too. Tramps” (D0172, p.17). As well, we learned that, "If a grade 9 did it with a grade 11, they'll tell their friends, cause you'd get a reputation for being a school slut, sleeping around” (D0178) and “Like the guy’s friends have girl friends, the girls will go confront the younger girl that's flirting with the older guy ...like if you were with a really popular guy and one of the [older] girls liked him, she'd probably get confronted" (D0177, p.17). We were also told that "Girls can get used to people commenting on their bodies - they develop immunity” (D0179 p.2).

We learned from the girls that that, "Half the guys in the school act tough, beat people up, call people names - intimidate people from doing anything about it” (D0177/78, p.4); "Leaders in school are stuck-up, too good for others - mostly guys [1520 guys and 7 girls]. ...There are no real dominant girls” (D0179, pp.1-2). In fact girls saw themselves as having to be on guard largely against popular males: "I don't like walking in the halls....They [the more popular kids] call you all sorts of names. Some times they'll make fun of your clothes or hair, anything they can make fun of. It's 
basically a big group of kids in grade 9 , mostly guys, not as many girls. (D0175, p.2) ... That big group of people calls people fag or gay, like if you're not, they say it no matter what, like if you walk by they say it” (D0175, p.4). ... “The [popular] guys will tell other guys what to think about their own girlfriends, but girls are just happy to have a boyfriend so they don’t complain” (D0179, p.1).

The boys we interviewed confirmed the girls’ perspectives and explanations. They acknowledged a preference for name-calling and swearing because, "Like you can deal with a ton of stuff by just talking to people. ...[M]ost of the time I yell a lot more than I do get physical. ... [I]f you can yell the most and get more power over them by yelling then that seems to get them [backed] down" (D0219, pp.15-16); and "Everyday [I hear name-calling]. Oh yeah. And it gets worse. My God, it’s like boom, boom, boom, boom. Pretty verbal at each other... but I never heard a guy called a slut, just girls, and I think I'd rather be known as a squealer than a slut if I was a girl. Not even that; like I'd rather like go to another school, like when you go to your next school that you're not considered a slut there and like it can kind of be left behind. People just kind of forget about that kind of stuff. They don't forget if you're a slut (D0164, p.24)...It's the bigger guys who do the name-calling mostly. The bigger guys, the more popular guys, cause they think 'We're better than you guys'” (D0164, p.19).

The responses that youth provided focused on the use of direct aggression by a particular group of "popular" boys in the school. These findings suggest that ultimately it is boys, especially the popular boys, who control the social hierarchy and exercise social dominance over both boys and girls. Interestingly while girls noted the daily experience of being on the receiving end of sexualized comments and verbal name calling from 
boys, the boys focused more on their experiences of boy-on-boy verbal aggression centered on achieving power over other boys, while highlighting girl-on girl sexualized verbal aggression focused on commenting on and controlling girls' sexuality. Ultimately, it appears that it is the way in which boys use direct verbal aggression that tends to capture the attention of both girls and boys and holds male dominance and dominant males in place.

\section{Discussion}

Our first finding that males reported significantly higher use of the most serious form of aggression "beating up another kid" confirms once again that boys do indeed consistently engage in the more serious physical forms of aggression more often than girls do. Still, the girls in our study did report beating up other kids even if they did so at significantly lower rates than boys, and we found that both males and females reported in engaging in all the aggressive behaviors that we queried, even though they did this at different rates. As well, based on our examination of preferences for the use of the various behaviors we studied, girls prefer direct aggression to indirect aggression just as boys do. With respect to girls’ preference, like that of boys, for using direct aggression over indirect aggression, we note that the most prevalent forms of direct aggression reported in our study coincide with what others (c.f., Atkin, et al., 2002; Björkqvist, et al., 1992; Peterson \& Rigby, 1999; Batchelor, Burman, \& Brown, 2001; Yubero \& Navarro, 2006) have indicated to be the most commonly used form of aggression in adolescent populations: verbal aggression. The form of directly aggressive behavior ranked third by girls in our study was pushing and shoving. However, despite its place among the preferred forms of aggression used, our frequencies show that only half the girls in our 
sample ever pushed/shoved males, and less than $40 \%$ ever pushed/shoved females. As a preferred form of aggression, however, pushing/shoving may show up because of its practical use in crowded school hallways when students are trying to move between classes. We did not ask whether pushing/shoving was enacted in order to harm someone. The question of why pushing/shoving is used, and to what effects, should be explored in future research.

We also found that both males and females crossed gender lines with respect to the sex of target of aggression, but that girls are more willing to cross those gender lines than boys. These findings seems to support research that shows that the use of aggression cannot be explained merely as the function of a fundamental sex difference (Adams, 1992, Miller 2001, 2002) and that there is no reason to believe that sex differences in motivation to aggress exist (Björkqvist \& Niemelä, 1992; Miller 2001 \& 2002).

Hawley and Vaughn, (2003) suggest that making choices about what form of aggression to employ hinges upon the status of the aggressor's relationship with a target and on the social sanctions associated with the use of aggression - that is the potential gains and losses for the person using aggression. Hilton, Harris and Rice (2000) found, as we did, that boys are generally more aggressive towards other boys and that females are more likely to use aggression towards the opposite-sex than are males. They also found that teenaged males are likely to underreport their use of aggression towards females. Perhaps this may have been at work in the results we obtained. Hilton, et al., (2000) suggest that such underreporting by males hinges upon their need to attend more to their abilities as aggressors against males in order to prevent potential harm. Female victims of males, in their capacity to harm boys less, are posited as less likely to warrant males’ 
enduring attention and therefore fall under the radar in self-reports of the use of aggression.

Another explanation for males’ lower propensity to aggress against females, or to underreport their female-directed aggression, is derived from a social sanction hypothesis (Harris, 1991). A social sanction hypothesis holds that the use of aggression is generally frowned upon and therefore likely to involve costs to the individuals who use it. Therefore individuals who use aggression need to be strategic in order to maximize their benefits (Pellegrini, et al., 2007). A cost-benefit explanation also rests upon the assumption that because males hold higher status within society, males’ interactions with other males, but not with females, are seen as important to achieving social dominance. Therefore males as high status individuals are less likely to challenge subordinates (i.e., females) because they perceive fewer benefits accruing from their efforts. The higher costs that are likely consequences of males' use of aggression towards females are suggested by Harris 1996) to be derived from cultural norms that posit male-to-male aggression as congruent with gender expectations and male to female aggression as gender-incongruent and therefore, socially unacceptable. Thus, in considering aggression towards a female, males are likely to be discouraged by the very real possibility that such action will prompt social disapproval (high cost) and help them little in their attempts to achieve dominance (low benefit).

Now that we have looked at possible explanations for males’ lower use, or underreporting of, their use of aggression toward the opposite sex, we consider possible explanations for females’ apparent willingness to use aggression against members of the opposite sex. The social sanction hypothesis offers a likely explanation here too. In 
general, female transgressions of gender norm boundaries are accepted to a greater extent than are male transgressions of gender boundaries (McCreary, 1994). In other words, we can safely assert that females are less likely to be judged negatively when they engage in aggressive behavior towards males, than are males who aggress towards females. There are limits, however, to the degree of aggression that will be tolerated by females. Females can face serious social disapproval when they transgress too far into the domain of aggression long-associated with males - that of serious physical aggression that goes beyond pushing and shoving. Social outrage and alarm at perceived female gender transgressions have been in evidence since the early 1990s, after females' use of violence became more widely documented. Since that time, girls who use aggression and violence have been variously described as “a contemporary crisis” (Alder \& Worrall, 2004, p. 1), much harder than to deal with than boys who use violence (Artz, Blais \& Nicholson, 2000; Baines \& Alder, 1996), devoid of the feminine and therefore demonic (ChesneyLind, 1999; Chesney-Lind \& Irwin, 2004), mean, manipulative and far more deviant than boys (Simmons, 2002; Tannenbaum, 1999), and generally so much worse.

Paradoxically, the alarmist characterizations of girls’ use of aggression and violence have the same origins as the greater acceptance of female sex role transgressions: a hegemonic vision of masculinity and dominant heterosexual male power in societies everywhere. As McCreary (1994) explained by using what she termed the social status hypothesis, as long as females hold less status than males, what females do is of less concern than what males do. Thus, according to McCreary, social status is inextricably entwined with social sanctions that are reflected in responses to females' use of aggression towards males, and since female behavior lies outside predominant 
concerns about heterosexual dominance, female behavior, even female behavior that deviates from a group's prescribed sex roles or ways of doing gender, is ultimately less of a concern than male behavior that deviates from a group's prescribed sex roles ways of doing gender. Further, homophobic attitudes coexist with a hegemonic vision of masculinity that considers heterosexuality to be the only acceptable form of sexual orientation. This hegemonic vision of masculinity also includes physical fighting between males as an essential part of healthy masculine development (Kimmel \& Mahler, 2003). Male-on-male aggression serves to uphold masculinity and dominant heterosexual male power, while female aggression, even female aggression against males is less likely to trigger fears about the downfall of heterosexuality than is the lack of a willingness by males to aggress against males.

Our interviews seem to support the notion that ultimately the way in which aggression and violence gets played out among adolescents serves to support dominant heterosexual male power. What youth told us about the use of these forms of direct aggression confirmed what Alder (1998) reported nearly ten years ago. That is, namecalling tends to focus on maintaining heterosexual dominance and critiquing the ways in which girls dress, their physical attractiveness, and girls' sexual reputations.

Alder (1998), who studied girls and their use of aggression and violence in Australia, pointed out that during adolescence girls experience the pressures of various forms of constraint that largely focus on inhibiting their sexuality. Girls' sexuality has long been associated with threats to masculinity and through association with compulsory heterosexuality, with threats to the nuclear family norm. Peers, parents, teachers, and other adults in a girl's world discourage her sexuality on the grounds of inherent danger 
for victimization (rape), disease, and unwanted pregnancy. The preservation of a chaste sexual identity is related to a girl's transition to dominant notions of adult feminine identity as a nurturing wife and mother subordinate to and dependent upon a male head of household. Thus, it is through sexual reputation that others (including girls) typically become involved in policing girls' behavior. A girl's reputation, especially her sexual reputation, is her most important social currency because a good (clean) sexual reputation coupled with high sexual desirability gives a girl a competitive edge in her quest for access to "a few good men," that is, the most socially powerful and desirable males (Campbell, 1995, p. 100). Holland, Ramazanoglu, Sharpe and Thompson (1998) speak to this notion of females' participation in the privileging of males' sexual expectations of females and in containing their own resistance to male domination as carrying "the male in the head, " which they suggest signals the asymmetry of [the] institutionalization and regulatory power of [males in] heterosexual relations” (p.171).

Artz (1997, 1998, 2000, 2005), the lead author, too found that girls' use of aggression and violence revolves primarily around attracting the male gaze and/or gaining the acceptance and approval of males. According to the participants in Artz's studies, girls can attain male approval either by maintaining an image and a reputation that preserves their desirability in the eyes of males or, should they not wish to compete for the male gaze on sexual terms, by demonstrating mental and physical toughness that includes the domination of other girls and being willing to take on boys in order to be accepted as equal to males on male terms.

Miller (2001, 2002) also describes the girls in her studies of gangs as "differentiating themselves from other young women through a construction of 'one of 
the guys' It was specifically girls' success at gender crossing that designated them as equals [to the guys]" (p.443), and therefore worthy of a higher place in their social order. All in all, whatever the explanation, the problem seems to be that male desire, standards, and frames of reference are dominant, thus trapping females within a "heterosexual contract” (Holland, Ramazanoglu, Sharpe \& Thompson, 1998. p. 171) with limited opportunity for stepping outside that contract.

Within our study, we conclude that a plausible explanation for girls' willingness to call boys names and swear at them more readily than boys appear to report behaving this way towards girls, may have to do either with girls defending their images and their reputations against girls and boys, or with wanting to demonstrate their ability to behave just like the boys with girls and boys. We also conclude that it is likely that the boys are also performing for the boys and are still primarily concerned with defending their images and reputations against boys. Both sexes appear to be engaged in practices that serve male dominance.

We struggle with accepting an explanation for female behavior that is premised largely on the dominance of males. Such an explanation still privileges males and derives female behavior in terms of males and thereby catches us in never-ending feedback loop that describes and understands females in terms of males. Although we seem to have moved beyond understanding direct and indirect aggression as kinds of behavior that can be understood simplistically as behaviors that are assigned according to sex, we still need to move beyond notions of sex role and gender that are restricted to understandings premised on, "He is playing masculine. She is playing feminine." and find ways to "call 
off that game” (Rozak \& Rozak, 1970. p. 330) in favor of a more complex and nuanced approach.

In order to take up the challenge of contributing to a more complex and nuanced approach to understanding sex role and gender, we will, in a subsequent article, undertake an analysis of our data that takes us beyond discrete sex differences into gender crossing. Miller (2002) will be helpful to us in our further work. While inquiring into gender crossing in her own research, she developed an extension and enhancement of Messerschmidt's $(1995,1997)$ theory that gender is not a trait, but a practice that is "situated” in other words, informed and grounded in our interpretations of our historical, social and cultural locations and therefore, far more than framework within which people fit themselves according to sex type. In doing so, Miller provides a far more complex and more open-ended approach to making sense of sex differences in the use of aggression and violence. Miller notes that, "a dualistic model of gender limits the ways in which social positioning based on such factors as gender, race class, sexuality and generation both intersect in the construction of identity and also offer contradictory schemas for identity construction and action” (p. 445).

It is our understanding that Miller (2002) would like to move us towards an understanding of gender that recognizes that we, in performing gender in our everyday lives, are doing more than carrying out a pre-determined exchange constrained by a variety of pre-ordained roles and rules that we assume as if we were donning apparel bought from the rack. Rather, she sees us as making choices that are informed by how we read the possibilities inherent in our location, and that even in adopting stereotypical practices, we may be doing so because we interpret these strategically as being in our 
own best interest given our situation. Thus, when young women in predominantly white, mixed working and middle class, suburban middle and high schools orient themselves toward the beacon of male acceptance, Miller's approach makes it possible to see these girls as enacting strategies for navigating this particular male dominated terrain, while not necessarily, once and for all, internalizing a pre-ordained sex role. This way of interpreting the actions of the participants in our study turns them into more than mere reproducers of a pre-existing social order; they become actors with agency. People who cross gender lines can be seen not only as challenging gender, but also as "border crossers” in Giroux’s (1996) terms. Giroux describes border crossers as people who "learn to negotiate the power, violence and cruelty of the dominant culture through [their] own lived histories, restricted languages and narrow cultural experiences” (p. 9), and thereby as breaking new ground. We see gender crossers as border crossers in a larger sense and therefore, as an important source of knowledge about aggression. We will now further mine our data about those participants, female and male, who crossed gender lines and engaged in the use of aggression against members of the opposite sex and hope to contribute to the enterprise of building a more finely tuned understanding of gender and aggression. 


\section{References}

Adams, D. (1992). Biology does not make men more aggressive than women. In K. Björkqvist and P. Niemelä (Eds.), Of mice and women: Aspects of female aggression (pp.17-25). San Diego, CA: Academic Press Inc.

Alder, C. (1998). "Passionate and willful” girls: Confronting practices. Women \& Criminal Justice, 9(4), 81-101.

Alder, C. \& Worrall, A (2004). A contemporary crisis? In C. Alder and A. Worrall (Eds.), Girls’ violence: Myths and realities (pp.1-20). Albany, NY: State University of New York Press.

Archer, J. (2004). Sex differences in aggression in real-world settings: A meta-analytic review. Review of General Psychology, 8 (4), 291-322.

Artz, S. (1997). On becoming an object: Sex and the violent school girl. Journal of Child \& Youth Care, 1(2), 17-38.

Artz, S. (1998). Sex, power, and the violent school girl. Toronto, Ontario: Trifolium Books.

Artz, S. (2000). The guys here degrade you: Youth perspectives on sex. Journal of Child and Youth Care, 14(4), 29-46.

Artz, S. (2005). To die for: Adolescent girls’ search for male attention. Pepler, D. \& Madsen, K., Webster, C. \& Levene, K. (Eds.), Development and Treatment of Girlhood Aggression (pp. 137-159). Hillsdale, NJ: Lawrence Erlbaum Associates Inc.

Artz, S. (2006). There's a violence out there: The challenges of school-based violence prevention. Paper presented at the First Bi-annual Alumni Conference: Child and 
Youth Care in Action, Victoria, B.C., May 25-26, 2006.

Artz, S., Blais, M., \& Nicholson, D. (2000). Developing Girls' Custody Units, Phase 1 Report to Justice Canada, Ottawa, ON.

Artz, S., \& Riecken, T. (1994a). A Study of violence among adolescent female students in a suburban school district. Ministry of Education, Research \& Evaluation Branch, and Gender Equity Programs.

Artz, S., \& Riecken, T. (1994b). Final Report: A Study of violence among adolescent female students in a suburban school district. For Gender Equity Programs, Ministry of Education and Ministry Responsible for Multiculturalism and Human Rights.

Artz, S., \& Riecken, T. (1995a). A Community Based Violence Project, First Quarter Report, B.C. Health Research Foundation.

Artz, S., \& Riecken, T. (1995b). Final Report: A Study of Violence Among Adolescent Female Students in a Suburban School District, for the Vancouver Foundation. Artz, S., Riecken, T., MacIntyre, B. \& Lam, E. (1997). A Community Based Violence Prevention Project, Fourth Quarter Report. Submitted to the BC Health Research Foundation.

Artz, S., Riecken, T., MacIntyre, B., Lam, E. \& Maczewski, M. (1998). A Community Based Violence Prevention Project, Sixth Quarter Report. Submitted to the BC Health Research Foundation.

Artz, S., Riecken, T., MacIntyre, B., Lam, E. \& Maczewski, M. (1999a). A Community Based Violence Prevention Project, Seventh Quarter Report. Submitted to the BC Health Research Foundation. 
Artz, S., Riecken, T., MacIntyre, B., Lam, E., \& Maczewski, M. (1999b). A Community Based Violence Prevention Project, Final Report. Submitted to the BC Health Research Foundation.

Artz, S., Riecken, T., MacIntyre, B., Lam, E. \& Maczewski, M. (2000). Theorizing gender differences in receptivity to violence prevention programs in schools. $B C$ Counselor, 22(1), 7-36.

Atkin, C., Smith, S., Roberto, A., Fediuk, T., \& Wagner, T. (2002). Correlates of verbally aggressive communication in adolescents. Journal of Applied Communication Research, 30 (3), 251-268.

Baines, \& Alder, C. (1996). Are girls more difficult to work with? Youth workers' perceptions in juvenile justice and related areas. Crime and Deliquency, 42, 467485.

Batchelor, S., Burman, M. and Brown, J. (2001) Discussing violence: let’s hear it for the girls. Probation Journal 48(2): 125-134.

Björkqvist, K. \& Niemelä, P. (1992). New trends in the study of female aggression. In K. Björkqvist and P. Niemelä (Eds.), Of mice and women: Aspects of female aggression (pp.3-16). San Diego, CA: Academic Press Inc.

Burman, M., Brown, J. and Batchelor, S. (2003) “"Taking it to heart”: girls and the meanings of violence' in E. Stanko (ed.) The Meanings of Violence. London: Routledge

Björkqvist, K., Österman, K., \& Kaukianen, A. (1992). The development of direct and indirect aggressive strategies in males and females. In K. Björkqvist and P. Niemelä (Eds.), Of mice and women: Aspects of female aggression (pp.51-64). 
San Diego, CA: Academic Press Inc.

Cairns, R., Cairns, B., Neckarman, H., Ferguson, L. \& Gariepy, J. (1989). Growth and aggression: 1. Childhood to early adolescence. Developmental Psychology, 25, 320-330.

Campbell, A. (1995). A few good men: Evolutionary psychology and female adolescent aggression. Ethnology and Sociobiology, 16, 100-123.

Card, N., Hodges, E., Little, T., \& Hawley, H. (2005). Gender effects in peer nominations for aggression and social status. International Journal of Behavioral Development, 29 (2), 146-155.

Chesney-Lind, M. (1999). Media Misogyny: Demonizing “violent” girls and women. In J. Ferrell and N. Websdale (Eds.), Making trouble: Cultural constructions of crime, deviance, and control (pp.115-140). New York, NY: Aldine de Gruyter.

Chesney-Lind, M. \& Irwin, K. (2004). From badness to meanness Popular constructions of contemporary girlhood. In A. Harris (Ed.), All about the girl: Culture, power and identity (pp.45-56). New York, NY: Routledge.

Craig, W. (1998). The relationship among bullying, victimization, depression, anxiety, and aggression in elementary school children. Journal of Personality and Individual Differences, 24, 123-130.

Crick, N. (1993). Relational aggression: Gender differences in the expression of aggressive behavior. In S. Asher (Chair), Social relationships, social beliefs, and aggression. Symposium conducted at the annual general meeting of the American Psychological Association, August 1993, Toronto, Canada. 
Crick, N. \& Grotpeter, J. (1995). Relational aggression, gender, and social-psychological adjustment. Child Development, 66, 710-722.

Crick, N. \& Grotpeter, J. (1996). Children’s treatment by peers: Victims of relational and overt aggression. Development and Psychopathology, 8, 367-380.

Cullerton-Sen, C. \& Crick, N. (2005). Understanding the effects of physical and relational victimization: The utility of multiple perspectives in predicting socialemotional adjustment. School Psychology Review, 34(2), 147-160.

David, C., \& Kistner, J. (2000). Do positive self-perceptions have a "dark side"? Examination of the link between perceptual bias and aggression. Journal of Abnormal Child Psychology, 28(4), 327-337.

Doob, A. \& Cesaroni, (2004). Responding to youth crime in Canada. Toronto, ON: University of Toronto Press.

Galen, B. \& Underwood, M. (1997). A developmental investigation of social aggression among children. Developmental Psychology, 33, 589-600.

Geiger, T., Zimmer-Gembeck, M., \& Crick, N. (2004). The science of relational aggression: Can we guide intervention? In M. Moretti, C. Odgers and M. Jackson (Eds.), Girls and Aggression: Contributing factors and intervention principles (pp.27-40). New York, NY: Kluwer.

Gendreau, P. \& Archer, J. (2005). Subtypes of aggression in humans and animals. In R. Tremblay, W. Hartup, and J. Archer (Eds.), Developmental origins of aggression (pp.25-46). New York, NY: Guilford Press.

Giroux, H. (1996). Fugitive cultures: Race, violence and youth. New York, NY: Routledge. 
Harris, M. (1991). Effects of sex of target, sex of aggressor and relationship on evaluations of physical aggression. Journal of Interpersonal Violence, 6(2), 174186.

Harris, M.(1996). Aggression, gender and ethnicity. Aggression and Violent Behavior, 1(2), 123-146.

Hawley, P. \& Vaughn, B. (2003). Aggression and adaptive functioning: The bright side to bad behavior. Merrill-Palmer Quarterly, 39 (3), 239-242.

Henington, C., Hughes, J., Cavell, T., \& Thompson, B. (1998). The role of relational aggression in identifying aggressive boys and girls. Journal of School Psychology, 36 (4), 457-477.

Hilton, N., Harris, G., \& Rice, M. (2000). The functions of aggression by male teenagers. Journal of Personality and Social Psychology, 79(6), 988-994.

Hindelang, M., Hirschi, T., \& Weis, J. (1981). Measuring delinquency. Beverly Hills, CA: Sage.

Holland, J., Ramazanoglu, C., Sharpe, S. and Thomson, R. (1998) The Male in the Head: Young people, heterosexuality and power. London: Tufnell Press.

Kimmel, M. \& Mahler, M. (2003). Adolescent masculinity, homophobia and violence: Random school shootings, 1982-2001. American Behavioral Scientist, 46(1), 1439-1458.

Lagerspetz, K.M.J., Björkqvist, K., \& Peltonen, T. (1988). Is indirect aggression typical of females? Gender differences in aggressiveness in 11- to 12-year old children. Aggressive Behavior, 14, 403-414. 
Lahelma, E. (2002). Gendered conflicts in secondary school: Fun or enactment of power? Gender and Education, 14 (3), 295-306.

Little, T., Jones, S., Henrich, C., \& Hawley, P. (2003). Disentangling the “whys” from the "whats" of aggressive behavior. International Journal of Behavioral Development, 27 (2), 122-133.

McCreary, D. (1994). The male role and avoiding femininity. Sex Roles, 31(9/10), 517531.

Messerschmidt, J. (1995) 'From patriarchy to gender: feminist theory, criminology and the challenge of diversity' in N. H. Rafter and F. Heidensohn (eds.) International Feminist Perspectives in Criminology. London: Sage.

Messerschmidt, J. (1997) Crime as Structured Action: Gender, race, class, and crime in the making. London: Sage.

Miller, J. (2001) One of the Guys: Girls, gangs and gender. New York: Oxford University Press.

Miller, J. (2002) The strengths and limits of ‘doing gender’ for understanding street crime. Theoretical Criminology 6(4): 433-460.

Pellegrini, A., Roseth, C., Milner, S., Bohn, C., Van Ryzin, M., Vance, N., Cheatham, C., \& Tarullo, A. (2007). Social dominance in preschool classrooms. Journal of Comparative Psychology, 121(1), 54-64.

Peterson, L. \& Rigby, K. (1999). Countering bullying at an Australian secondary school with students as helpers. Journal of Adolescence, 22, 481-492. 
Riecken, T., Artz, S., MacIntyre, B., Lam, E. \& Maczewski, M. (1998). A Community Based Violence Prevention Project, Fifth Quarter Report. Submitted to the BC Health Research Foundation.

Richardson, D. \& Green, L. (1999). Social sanction and threat explanations of gender effects on direct and indirect aggression. Aggressive Behavior, 25, 425-434.

Richardson, D., \& Green, L. (2006). Direct and indirect aggression: Relationships as social context. Journal of Applied Social Psychology, 36(10), 2492-2508.

Roecker, C., Caprini, J., Dickerson, J., Parks, E., \& Barton, A. (1999). Children’s responses to overt and relational aggression. Paper presented at the Biennial Meeting of the Society for Research in Child Development, Albuquerque, March.

Rozak, T. \& Rozak, B. (Eds), (1970). Masculine and feminine. New York, NY: Harper and Row.

Simmons, R. (2002). Odd girl out. New York, NY: Harcourt, Inc.

Smith, P., Cowie, H., Olafsson, R., \& Liefooghe, A. (2002). Definitions of bullying: A comparison of terms used, and age and gender differences in a fourteen-country international comparison. Child Development, 73(4), 1119-1133.

Sprott, J. \& Doob, A. (2004). Youth Justice in Canada. In M. Tonry and A. Doob (Eds.), Crime and Justice: A Review of the Research. Volume 31 (pp. 185-242). Chicago, IL: University of Chicago Press.

Tannenbaum, L. (1999). Slut! Growing up female with a bad reputation. New York, NY: Seven Stories Press.

Tremblay, J. (2000). The origins of youth violence. Isuma: The Canadian Journal of Policy Research, 1(2), 19-24.

Vaillancourt, T. (2005). Indirect aggression among humans: Social construct or evolutionary adaptation? In R. Tremblay, W. Hartup, and J. Archer (Eds.), Developmental origins of aggression (158-177). New York, NY: Guilford Press. 
Vaillancourt, T. \& Hymel, S. (2004). The social context of children’s aggression. In Girls and aggression: Contributing factors and intervention principles (pp.57-73). New York, NY: Kluwer.

Werner, N. \& Nixon, C. (2005). Normative beliefs and relational aggression: An investigation of the cognitive bases of adolescent aggressive behavior. Journal of Youth and Adolescence, 34 (3), 229-243.

Whitmer, B. (1997). The violence mythos. Albany, NY: SUNY Press.

Xie, H., Cairns, R. \& Cairns, B. (2002). The development of social aggression and physical aggression: A narrative analysis of interpersonal conflicts. Aggressive Behavior, 28, 341-355.

Yubero, S. \& Navarro, R. (2006). Students' and teachers' views of gender-related aspects of aggression. School Psychology International, 27 (4), 488-512.

Zimmer-Gembeck, M., Geiger, T., \& Crick, N. (2005). Relational and physical aggression, prosocial behavior, and peer relations: Gender moderation and bidirectional associations. Journal of Early Adolescence, 25(4), 421-452. 
Table 1. Prevalence of Use of Specific Aggressive Behaviors

$$
\text { Males }(n=146) \quad \text { Females }(n=118)
$$

Aggressive Behaviors Never $\quad \underline{1-3}$ times 4-9 times10+ $\quad$ Never 1-3 times 4-9 times $\quad$ 10+

\begin{tabular}{lrrrrrrrr} 
& & & \multicolumn{2}{c}{ times } & & \multicolumn{3}{c}{$\underline{\text { times }}$} \\
Called Males Names & $20.5 \%$ & $33.6 \%$ & $13.7 \%$ & $28.1 \%$ & $44.1 \%$ & $39.8 \%$ & $9.3 \%$ & $3.4 \%$ \\
Swore at Males & $27.4 \%$ & $25.3 \%$ & $13.0 \%$ & $39.5 \%$ & $49.2 \%$ & $33.1 \%$ & $8.5 \%$ & $5.1 \%$ \\
Pushed/shoved Males & $27.4 \%$ & $31.5 \%$ & $17.1 \%$ & $17.8 \%$ & $52.5 \%$ & $36.4 \%$ & $3.4 \%$ & $4.2 \%$ \\
Threatened Males & $51.4 \%$ & $24.0 \%$ & $8.2 \%$ & $11.6 \%$ & $81.4 \%$ & $13.6 \%$ & $0.8 \%$ & $0.8 \%$ \\
Excluded/shunned & $65.1 \%$ & $20.5 \%$ & $3.4 \%$ & $5.5 \%$ & $68.6 \%$ & $22.0 \%$ & $3.4 \%$ & $2.5 \%$
\end{tabular}
Males

\begin{tabular}{|c|c|c|c|c|c|c|c|c|}
\hline $\begin{array}{l}\text { Spread rumors about } \\
\text { Males }\end{array}$ & $80.8 \%$ & $11.6 \%$ & $2.1 \%$ & $0.7 \%$ & $88.1 \%$ & $6.8 \%$ & $1.7 \%$ & $0.0 \%$ \\
\hline Blackmailed Males & $85.6 \%$ & $6.2 \%$ & $1.4 \%$ & $2.1 \%$ & $94.9 \%$ & $0.8 \%$ & $0.8 \%$ & $0.0 \%$ \\
\hline $\begin{array}{l}\text { Damaged Males' } \\
\text { property }\end{array}$ & $67.8 \%$ & $22.6 \%$ & $2.1 \%$ & $2.7 \%$ & $89.0 \%$ & $5.9 \%$ & $0.8 \%$ & $0.0 \%$ \\
\hline Called Females & $50.7 \%$ & $24.7 \%$ & $9.6 \%$ & $7.5 \%$ & $39.8 \%$ & $45.8 \%$ & $5.9 \%$ & $5.1 \%$ \\
\hline \multicolumn{9}{|l|}{ Names } \\
\hline Swore at Females & $54.8 \%$ & $23.3 \%$ & $6.2 \%$ & $8.2 \%$ & $52.5 \%$ & $30.5 \%$ & $5.9 \%$ & $6.8 \%$ \\
\hline Pushed/shoved & $77.4 \%$ & $10.3 \%$ & $2.1 \%$ & $2.1 \%$ & $63.6 \%$ & $24.6 \%$ & $5.9 \%$ & $2.5 \%$ \\
\hline \multicolumn{9}{|l|}{ Females } \\
\hline Threatened Females & $88.4 \%$ & $2.1 \%$ & $0.0 \%$ & $2.1 \%$ & $78.0 \%$ & $12.7 \%$ & $2.5 \%$ & $2.5 \%$ \\
\hline $\begin{array}{l}\text { Excluded/shunned } \\
\text { Females }\end{array}$ & $78.1 \%$ & $10.3 \%$ & $2.1 \%$ & $1.4 \%$ & $73.7 \%$ & $20.3 \%$ & $0.8 \%$ & $1.7 \%$ \\
\hline $\begin{array}{l}\text { Spread rumors about } \\
\text { Females }\end{array}$ & $81.5 \%$ & $8.9 \%$ & $0.7 \%$ & $0.7 \%$ & $85.6 \%$ & $9.3 \%$ & $0.0 \%$ & $1.7 \%$ \\
\hline Blackmailed Females & $89.0 \%$ & $2.1 \%$ & $0.0 \%$ & $0.7 \%$ & $93.2 \%$ & $0.8 \%$ & $0.0 \%$ & $1.7 \%$ \\
\hline $\begin{array}{l}\text { Damaged Females' } \\
\text { property }\end{array}$ & $87.0 \%$ & $4.1 \%$ & $0.0 \%$ & $0.7 \%$ & $87.3 \%$ & $8.5 \%$ & $0.0 \%$ & 0.8 \\
\hline
\end{tabular}


Table 2. Sex Differences for the Use of Direct and Indirect Aggressive Behaviors

$$
\text { Males }(n=146) \quad \text { Females }(n=118)
$$

\begin{tabular}{|c|c|c|c|c|}
\hline \multirow[b]{2}{*}{ Direct Aggression } & \multirow[b]{2}{*}{ Mean } & \multirow[b]{2}{*}{$\underline{\mathrm{SD}}$} & \multirow[b]{2}{*}{$\underline{\text { Mean }}$} & \multirow[b]{2}{*}{$\underline{\mathrm{SD}}$} \\
\hline & & & & \\
\hline Called Males Names $* * *$ & 1.51 & 1.13 & 0.71 & 0.78 \\
\hline Swore at Males *** & 1.47 & 1.21 & 0.68 & 0.85 \\
\hline Pushed/shoved Males *** & 1.27 & 1.08 & 0.58 & 0.76 \\
\hline Threatened Males *** & 0.79 & 1.04 & 0.18 & 0.47 \\
\hline Called Females Names & 0.72 & 0.95 & 0.75 & 0.79 \\
\hline Swore at Females & 0.65 & 0.95 & 0.65 & 0.88 \\
\hline Pushed/shoved Females ** & 0.22 & 0.60 & 0.46 & 0.73 \\
\hline Threatened Females ** & 0.09 & 0.47 & 0.27 & 0.64 \\
\hline \multicolumn{5}{|l|}{ Indirect Aggression } \\
\hline Excluded/shunned Males & 0.46 & 0.82 & 0.38 & 0.68 \\
\hline Spread rumors about Males & 0.19 & 0.49 & 0.11 & 0.36 \\
\hline Blackmailed Males ** & 0.16 & 0.54 & 0.03 & 0.21 \\
\hline Damaged Males’ Property *** & 0.37 & 0.68 & 0.08 & 0.30 \\
\hline Excluded/shunned Females & 0.20 & 0.55 & 0.28 & 0.57 \\
\hline Spread rumors about Females & 0.13 & 0.42 & 0.15 & 0.48 \\
\hline Blackmailed Females & 0.04 & 0.30 & 0.06 & 0.40 \\
\hline Damaged Females’ Property & 0.07 & 0.33 & 0.11 & 0.39 \\
\hline
\end{tabular}


Table 3. Sex Differences for Prevalence of Use of Direct and Indirect Aggressive Behaviors

\begin{tabular}{lccccc} 
& \multicolumn{3}{c}{ Males $(\mathrm{n}=146)$} & \multicolumn{2}{c}{ Females $(\mathrm{n}=118)$} \\
\cline { 2 - 5 } & $\underline{\text { Mean }}$ & $\underline{\underline{\text { SD }}}$ & $\underline{\underline{\text { Mean }}}$ & $\underline{\underline{\mathrm{SD}}}$ \\
Use of Direct Aggressive Behaviors *** & 6.62 & 5.34 & 4.23 & 4.28 \\
Use of Indirect Aggressive Behaviors & 1.60 & 2.82 & 1.18 & 2.56
\end{tabular}

- $\mathrm{p}<.05 ; * * \mathrm{p}<.01 ; * * * \mathrm{p}<.001$ (two-tailed) 
Table 4. Ranked Use of Specific Aggressive Behaviors for Males

\begin{tabular}{|c|c|c|}
\hline \multirow[b]{2}{*}{ Aggressive behaviors } & \multicolumn{2}{|c|}{ Males (n=146) } \\
\hline & $\underline{\text { Mean }}$ & $\underline{\mathrm{SD}}$ \\
\hline Called Males Names & 1.51 & 1.13 \\
\hline Swore at Males & 1.47 & 1.21 \\
\hline Pushed/shoved Males & 1.27 & 1.08 \\
\hline Threatened Males & 0.79 & 1.04 \\
\hline Called Females Names & 0.72 & 0.95 \\
\hline Swore at Females & 0.65 & 0.95 \\
\hline Excluded/shunned Males & 0.46 & 0.82 \\
\hline Damaged Males’ Property & 0.37 & 0.68 \\
\hline Pushed/shoved Females & 0.22 & 0.60 \\
\hline Excluded/shunned Females & 0.20 & 0.55 \\
\hline Spread rumors about Males & 0.19 & 0.49 \\
\hline Blackmailed Males & 0.16 & 0.54 \\
\hline Spread rumors about Females & 0.13 & 0.42 \\
\hline Threatened Females & 0.09 & 0.47 \\
\hline Damaged Females’ Property & 0.07 & 0.33 \\
\hline Blackmailed Females & 0.04 & 0.30 \\
\hline
\end{tabular}


Table 5. Ranked Use of Specific Aggressive Behaviors for Females

Females $(\mathrm{n}=118)$

Aggressive Behaviors

Called Females Names

Called Males Names

Swore at Males

Swore at Females

Pushed/shoved Males

Pushed/shoved Females

Excluded/shunned Males

Excluded/shunned Females

Threatened Females

Threatened Males

Spread rumors about Females

Spread rumors about Males

Damaged Females’ Property

Damaged Males' Property

Blackmailed Females

Blackmailed Males

Mean $\quad \underline{\text { SD }}$

$\begin{array}{ll}0.75 & 0.79\end{array}$

$\begin{array}{ll}0.71 & 0.78\end{array}$

$0.68 \quad 0.85$

$0.65 \quad 0.88$

$0.58 \quad 0.76$

$0.46 \quad 0.73$

$0.38 \quad 0.68$

$0.28 \quad 0.57$

$0.27 \quad 0.64$

$\begin{array}{ll}0.18 & 0.47\end{array}$

$0.15 \quad 0.48$

$0.11 \quad 0.36$

$0.11 \quad 0.39$

$\begin{array}{ll}0.08 & 0.30\end{array}$

$0.06 \quad 0.40$

$\begin{array}{ll}0.03 & 0.21\end{array}$


Table 6. Self-Reported Use of Direct Aggressive Behaviors

\begin{tabular}{lcc} 
& $\begin{array}{c}\text { Same-Sex Target } \\
\text { Direct Aggression }\end{array}$ & $\begin{array}{c}\text { Opposite-Sex Target } \\
\text { Direct Aggression }\end{array}$ \\
\hline Used & 661 & 375 \\
Not used & 677 & 896
\end{tabular}

Table 7. Self-Reported Use of Indirect Aggressive Behaviors

\begin{tabular}{lcc} 
& $\begin{array}{l}\text { Same-Sex Target } \\
\text { Indirect Aggression }\end{array}$ & $\begin{array}{l}\text { Opposite-Sex Target } \\
\text { Indirect Aggression }\end{array}$ \\
\hline Used & 217 & 142 \\
Not used & 1109 & 1079
\end{tabular}

